また衝撃曲げ試験と静的曲げ試験との結果を比較し てみるとは同庫の試験とよるのが最も望ましく, 現在 準備中である。四筒状試験片について Obert らが行 つを絓果によると, 岩石の曲げ破壊係数 (modulus of rupture)将岩, 大理石, 花崗岩の順に大きく, か礼 らの行つた Page 衝撃試験の結果と同順てなつている.

まを衝撃試験片の破面の状態から材料の勒脆の程度 を判別するととは，金属の場合飞はある程度可能のよ

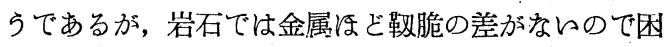
難と思われる。

実験飞協力さ祃を京大工学部鉱山学教室段野教官, 佐竹大学院学生, ならびて試験装置について援助され
そ京大工学部機峨教室に対し謝意を表する。

* 曲げ破壞係数 Rは次式であらわされる.ただし $P$ は破壊荷重, $l$ は支点間距離， $d$ は試騟片の直径である，

$$
R=\frac{8 P l}{\pi d^{3}}
$$

注: 一

1) ASTM, Designation D 3-18, ASTM Standards, Part II, p. 427 (1942)

2) Report of Investigation, No. 3891, U.S. Bureau of Mines, p.p. 41 45 (1946)

3) M. Freudenthal, The Inelastic Behaviour of Engineering Materials and Structures, London, pp. $555 \sim 559^{\circ}$ (1950)

4) ibid. 2), pp. $43 \sim 45$

5) ibid. 2), pp. $23 \sim 26$

\title{
引抜材の機械的性質に関する研究*
}

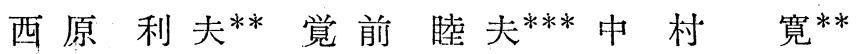

\section{Experimental Research on Mechanical Properties of Drawn Wire}

\section{Toshio Nishinara, Mutsuo Kakuzen and Hiroshi Nakamura}

This parer deals with the experimental research on the effects of change of wire drawing condition on hardness distribution over the section of drawn wire.

Using a Micro-Vickers hardness tester, we tried to investigate the hardness distribution over the cross section of three kinds of carbon steel wires and a brass wire, drawn under several kinds of drawing conditions, as well as the gradual change of hardness over the longitudinal section of carbon steel wires under plastic deformation with half drawn specimen.

As the results we have make it clear that the wire with uniform deformation as possible will be obtained by following methods of drawing:

(1) with the die of larger radius of curvature of drawing surface than with the die of smaller radius,

(2) under high reduction of diameter than low reduction.

\section{1. 緒言}

引拢条件が線材の個々の機械的性質に及㳊す影響に 関しては従来種々の研究がなされているが，引拢条件 と線材の機械的諸性質との総合的な関保についてはを だあまり明らかにされて和らず，鈴木弘氏の研究があ るに過をないような状態である。

われわれはさきに二次曲線ダイスについて引抜応力 の計算式を導き，数值計算により引抜条件が引抜応力

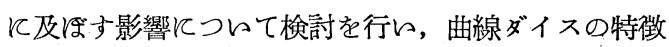

\footnotetext{
* 原稿受付 昭和 30 年 2 月 9 日 日本材料試験拹会第 3 期䌊会に 扎てて满演

** 正員 京都大学

$* * *$ 正員 同志社大学
}

を明らかにし,さらに引抜応力の計算飞必要な引抜時 飞和ける摩擦保数の值を測定し，乙れを用的て引拢㐫 力の計算結果が実際の值とよく一致するととを実験的 そ確かめたのであるが，諸種の条件のもとに引抜いた 線材について機找的諸性質を測定し, 引拢条件がこれ

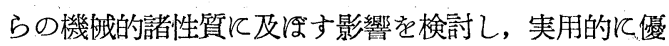
れを性質をもつた線材を得るための引抜条件を求好る ととを目的として行う研究のうち, 本文では線材の硬 度に及深す引抜条件の影響を明らかにするために行つ そ実験につレて報告する。

\section{2. 引抜線材の硬度分布}

ダイスによつて線材が引抜かれる場合, 線材が不均 
一な変形加工を受けるととは G. Sachs, 鈴木弘らの 諸氏の研究結果からも明らかなととである。すねわち 変形過程の解析の結果によれば, 中心部より外層部の 方がより大なる剪断歪を受け，したがつて加工硬化を 起しす材料では, 引抜の際に発生する熱のための自己 焼鈍による軟化が無ければ, 引抜線材の断面上の硬度 は中心部で最小值を示し, 外層に近くなるに従つて高 ロ值を示す. 鈴木弘氏の電気銅棒についての実験結果 もそのような傾向を示している。

われわれは炭素含有量の異なる 3 種類の炭素鈴線材 和よび黄釦線材を, 引拔面の曲率の異なる 5 種類の四 弧回転面ダイスで引抜らた線材につレて, 横断面上の 硬度分布を測定し, ダイス形状, 引拔直径減少率, 末0 よど炭素含有量が硬度分布に及放響について検討 を行らまを引抜の途中の線材をダイスより逆化抜き 取り，断面上の硬度分布を測定し，ダイス中に和ける 変形過程に対与る考察を行つそ。

\section{3. 引抜、条、件}

引抜条件が線材の硬度分布に及に゙す影響を検討する そめには，引抜条件を明確にして和かね惢ならな。 硬度測定用の供試線材を得るためには，次に示すよう な条件で引抜をを行つた。

ダイス Fig. 1 和よび Table 1 亿示すような 5 種類の燒結合金製ダイスを用的を。

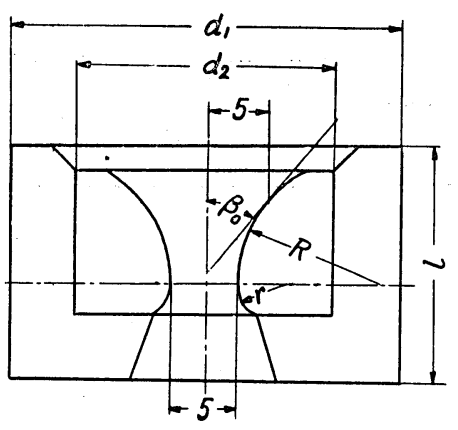

Fig. 1. Die.

Table 1.

\begin{tabular}{l|c|c|c|c|c|c}
\hline $\begin{array}{c}\text { Symbol } \\
\text { of die }\end{array}$ & $\begin{array}{c}\beta_{0} \\
(\text { deg. })\end{array}$ & $\begin{array}{c}R \\
(\mathrm{~mm})\end{array}$ & $\begin{array}{c}\boldsymbol{r} \\
(\mathrm{mm})\end{array}$ & $\begin{array}{c}\boldsymbol{l} \\
(\mathrm{mm})\end{array}$ & $\begin{array}{c}\boldsymbol{d}_{1} \\
(\mathrm{~mm})\end{array}$ & $\begin{array}{c}\boldsymbol{d}_{2} \\
(\mathrm{~mm})\end{array}$ \\
\hline $\mathrm{C}_{\mathrm{A}}$ & 10 & $164 \cdot 8$ & 10 & 40 & 85 & 35 \\
$\mathrm{C}_{\mathrm{B}}$ & 20 & 41.5 & 5 & 35 & 70 & 30 \\
$\mathrm{C}_{\mathrm{C}}$ & 30 & $18 \cdot 7$ & 5 & 25 & 48 & 24 \\
$\mathrm{C}_{\mathrm{D}}$ & 40 & 10.6 & $10 \cdot 6$ & 20 & 42 & 15 \\
$\mathrm{C}_{\mathrm{E}}$ & 50 & 7 & 7 & 20 & 42 & 15 \\
\hline
\end{tabular}

引抜線材 硬度分布測定用線材は Table 2 亿示す ような成分をもつ炭素鋼叔よど黄銅線材で，引抜前の 素線は真空中 $(0.1 \mathrm{~mm} \mathrm{Hg})$. て焼鈍, 残留丕を除去し そ. 各線材に対与焼钝条件を Table 3 亿示す。

昭和 30 年 5 月
Table 2. Chemical compcsition of wire (\%).

\begin{tabular}{|c|c|c|c|c|c|c|}
\hline & $\mathrm{C}$ & $\mathrm{Si}$ & $\mathrm{Mn}$ & & $\mathrm{P}$ & $\mathrm{S}$ \\
\hline \multirow{3}{*}{$\begin{array}{c}\text { Carbon } \\
\text { steel } \\
\text { wire }\end{array}$} & & & $0 \cdot 44$ & & \\
\hline & 0.41 & $0: 28$ & 0.49 & \multicolumn{2}{|r|}{0.007} & 0.025 \\
\hline & 0.60 & $0 \cdot 26$ & 0.53 & \multicolumn{2}{|r|}{0.006} & 0.027 \\
\hline & $\mathrm{Cu}$ & $\mathrm{Zn}$ & Sn & $\mathrm{Mn}$ & Al & $\mathrm{Fe}$ \\
\hline Brass wire & $59 \cdot 67$ & - & $0 \cdot 22$ & 0.8 & - & 0.3 \\
\hline
\end{tabular}

Table 3. Conditions of annealing.

\begin{tabular}{l|c|c}
\hline \multicolumn{1}{c|}{ Sorts of wire } & $\begin{array}{c}\text { Temperature of } \\
\text { annealing } \\
\left({ }^{\circ} \mathrm{C}\right)\end{array}$ & $\begin{array}{c}\text { Time of } \\
\text { annealing } \\
(\mathrm{min} .)\end{array}$ \\
\hline $\begin{array}{l}0.10 \% \text { carbon } \\
\text { steel wire }\end{array}$ & 880 & 30 \\
$\begin{array}{l}0.41 \% \text { carbon } \\
\text { steel wire }\end{array}$ & 800 & 30 \\
$\begin{array}{l}0.60 \% \text { carbon } \\
\text { steel wire }\end{array}$ & 770 & 30 \\
Brass wire & 600 & 30 \\
\hline
\end{tabular}

潤滑剂炭素鍍線材に対してはモビール油に少量 の機械油を加えたものを, 黄釦線材に対しては石灰石 瞼を潤滑剤として使用した。

引抜速度 引抜の際の熱の発生により, 硬度分布 が乱されるのを防ぐために毎分約 $40 \mathrm{~cm}$ とした。

\section{4. 実 験 方 法}

硬度の測定には明石製作所製の Vickers 微小硬度計 を使用し, 測定荷重を $500 \mathrm{~g}$, 荷重時間を 30 秒とし, 測定条件を一定に保ち，乙れの変動による誤差をでき るだけ少なくし，正確な值を得るように留意した。

横断面上の硬度分布を測定与るための試験片は, 引 抜前に焼鈍を施しした素線を Fig. 1 和よびTable 1 亿 示す各ダイスで引抜らた線材から系鋸で切り取り，ま す紙やすりで表面を研磨し，さらに研磨による表面の 加工硬化による影響をできるだけ除去するために, 最 後に電解研穈を行い測定面を鏡面に仕上げた。また引 抜中の変形過程に扣ける硬度の変化の状態をみるため そ, 可抜を途中で中止し, 逆にダイスから抜き取つた 線材を，その軸を含む面で縦に切断し，同様の研磨方 法で表面を仕上げた，糸鋸による切断ならびに研縻の 際には,温度の上昇を防ぐために充分の注意を払つた。

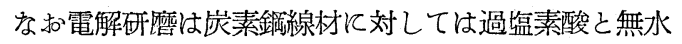
錯酸との混合液を, 黄銅線材に対しては正嶙酸に少量 のクローム酸を加えたものをそれそれ電解液として使 用し, 直流で行つた。

硬度は横断面に対しては直径上を約 $0.5 \mathrm{~mm}$ の間隔 で測定し，外周から約 $0.25 \mathrm{~mm}$ 内側のととろの硬度 をもつて最外層の硬度とした。縦断面上の硬度はダィ ス大口の手前から出口後までの間を一定の間隔で碁盤 
目状に測定した。

\section{5. 実 験 結。果}

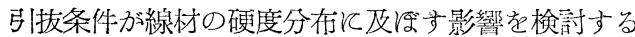
ことが目的であるから，引抜前の線材がそれまでの加 工によつて受けた影響が，㜔竏によつて完全飞除去さ れたか否かを確かめ当必要がある。その一方法とし て，焼鈍した線材につ的て硬度分布走測定した。Fig.2 飞示すよう飞, 引拢前の素線は均一尓硬度分布をして ロるととを確かめるととがでをた。
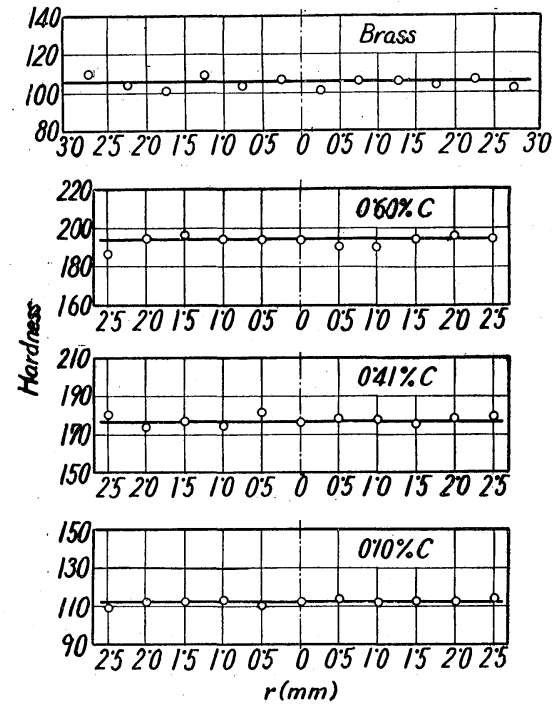

Fig. 2. Hardness distribution over the crcss section of the annealed wire.
このように均一な硬度分有をしている線材を Fig. 1 そ示すダイスで弓抜いた線材について硬度分布を測定

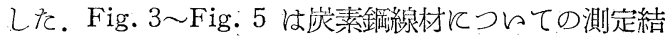
果を, Fig: 6 は黄銅線材についての測定綪果を示すも のである。同図中の各実験記号は使用したダイスの形 状ならび拢直径減少率の值走示すもので, Table 4 に一括して示与.

これらの実験結果から睄らか子るどとく，硬度分有 は质とんど例外なく中心部で最小となり，外層にゅく に良つて大になる傾向を示している。

\section{6. 硬度分布に及ぼす引抜条件の影響}

炭素鋼線材和よど黄銅線材の硬度分布の測定結果よ り，ダイス形状，引拢直径減少率，扣よび孷素含有量

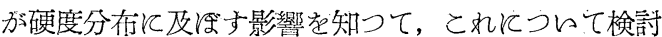

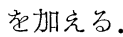

（1）ダイス形状の影響 線材の中心部の硬度は 引抜直径減少率が同じ場合には，ダイスの形状には無

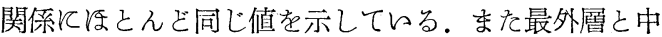
心部との硬度の差を $H_{V}{ }^{\prime}$ としてこれを縦軸ととり，横 軸にダイスの形を表わすパラメーター $\beta_{0}$ をとり，そ れぞれの線材について断面上の硬度差とがイスの形状 との関係を調べてみた。その結果 Fig. 7〜Fig. 10 K 示すように，引拢直径減少率には無関係に， $\beta_{0}$ が大に なるに徉がつて，交わち引抜面の四弧の半径が小に なるに徉つて硬度差 $H_{V}{ }^{\prime}$ が大になる傾向のあるととが わかり，とのととは前に報告した円弧ダイスによる引

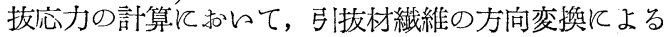
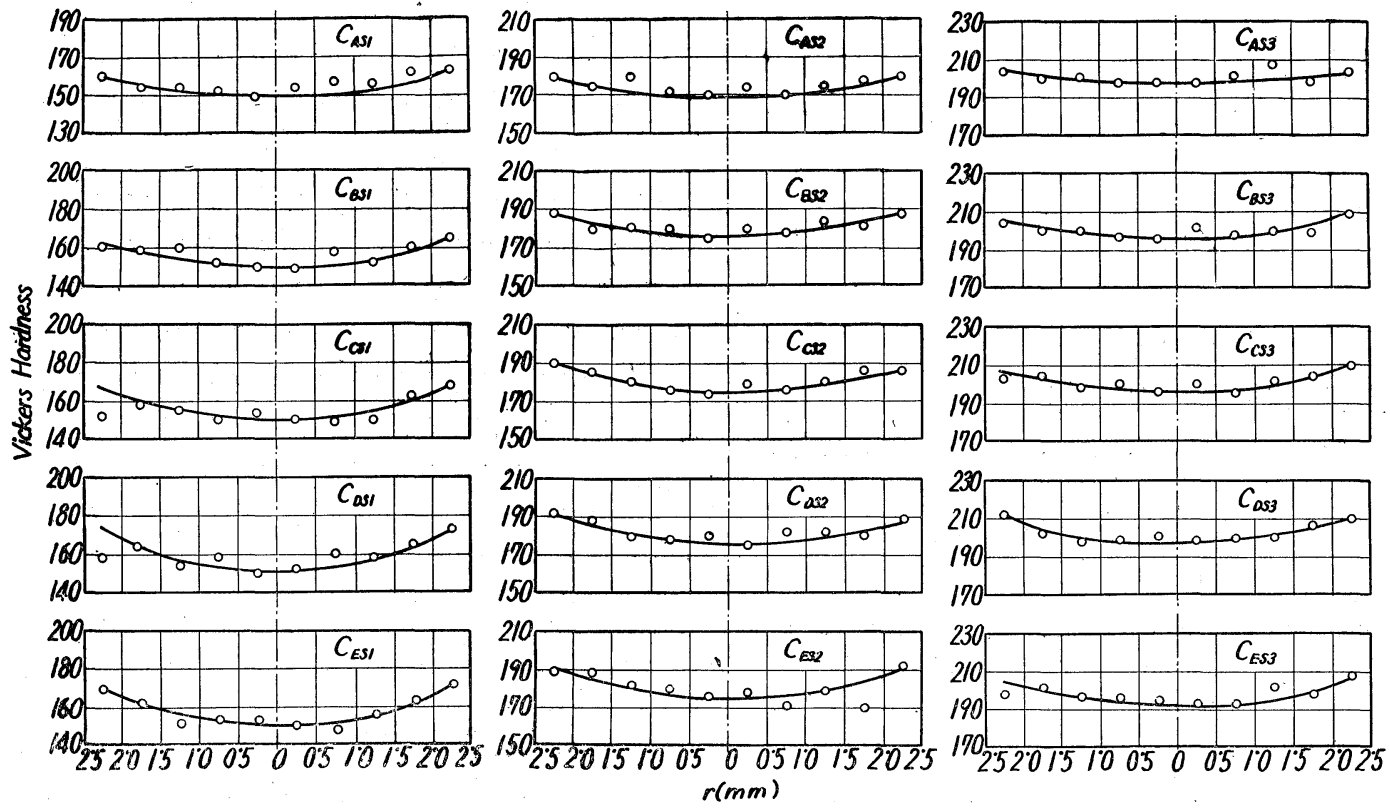

Fig. 3. Hardness distribution over the cross section of the drawn steel wire $(0.10 \% \mathrm{C})$. 

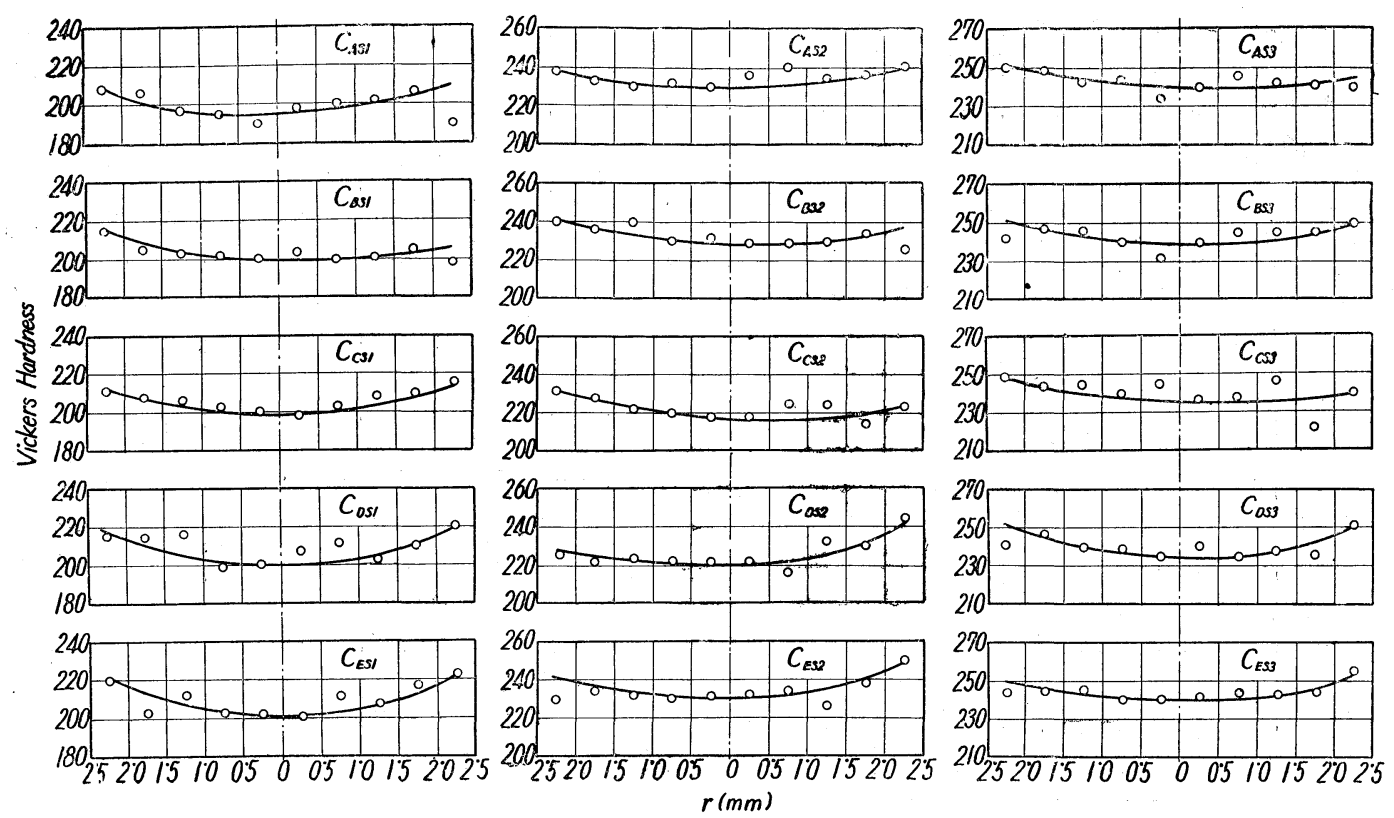

Fig. 4. Hardness distribution over the cross section of the drawn wire $(0 \cdot 41 \% \mathrm{C})$.
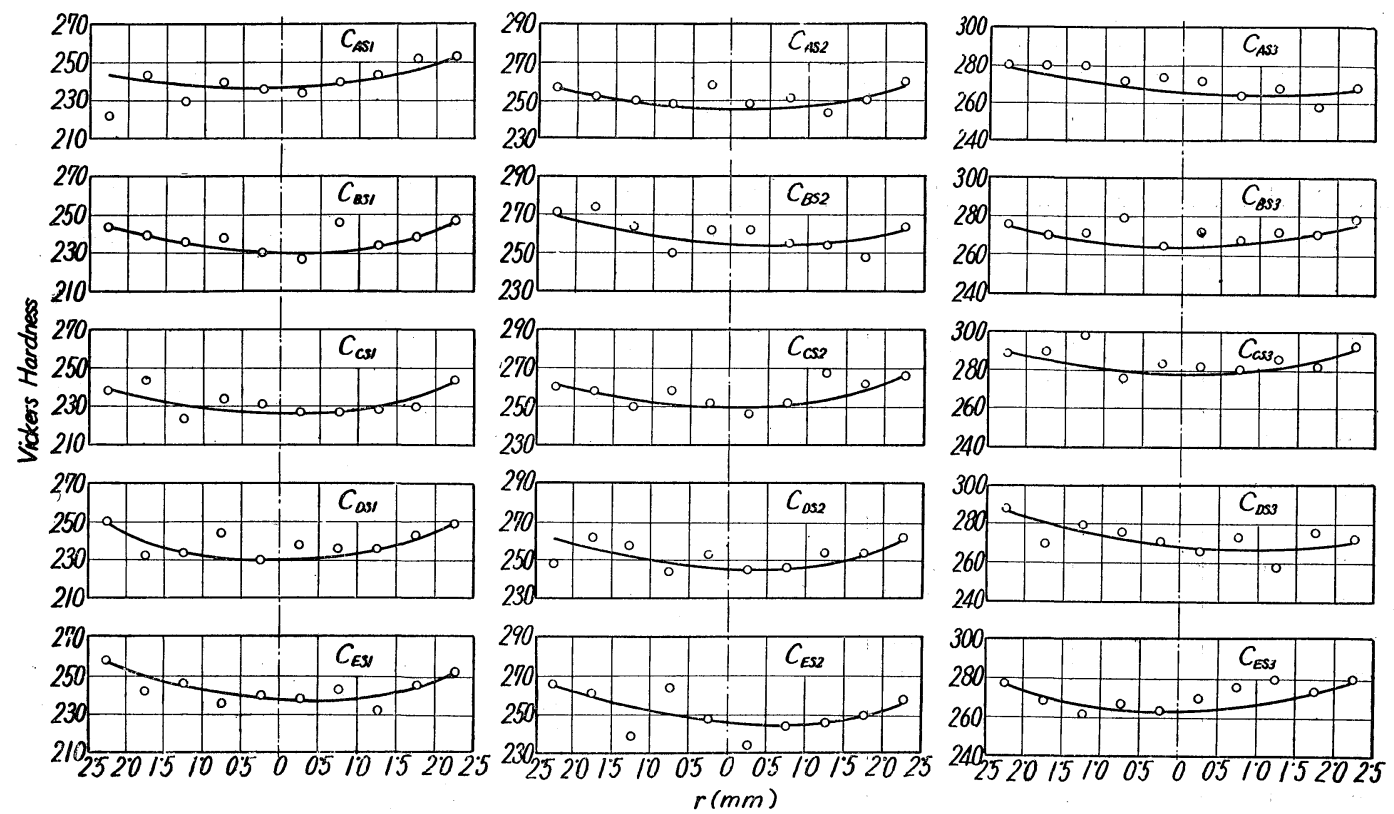

Fig. 5. Hardness distribution over the cross section of the drawn sieel wire $(0 \cdot 60 \% \mathrm{C})$.

増加応力が, $\beta_{0}$ の值が大になるに従つて増加するのと 同じ傾向で，がイスの引抜面の曲率が大になるほゼ引 拔材の外層部の受ける剪断仕事が, 中心部に比して增 大するととを裏付的している。

（2）引抜直径減少率の影響線材の中心部の硬 度を $H_{V}$ としてとれを縦軸に, 横軸に弓抜直径減少率 をとり, 中心部硬度と引抜直径減少率との関係を図示
すると, Fig. 11 利よび Fig. 12 のようとなる.中心 部硬度は加工度が増すとともに増す傾向を示してい る。すを縦軸に中心部と外膡部との硬度差 $H_{V}{ }^{\prime}$ を, 横 軸沉引抜值径減少率をとると，Fig. 13〜 Fig. 16 亿示 すように, 使用したダイスのいかんスかかわらす。加工 度が增すに往つて，逆に硬度差が減少する傾向を示す。 これは電気釗についての鈴木氏の結果とよく一致して 

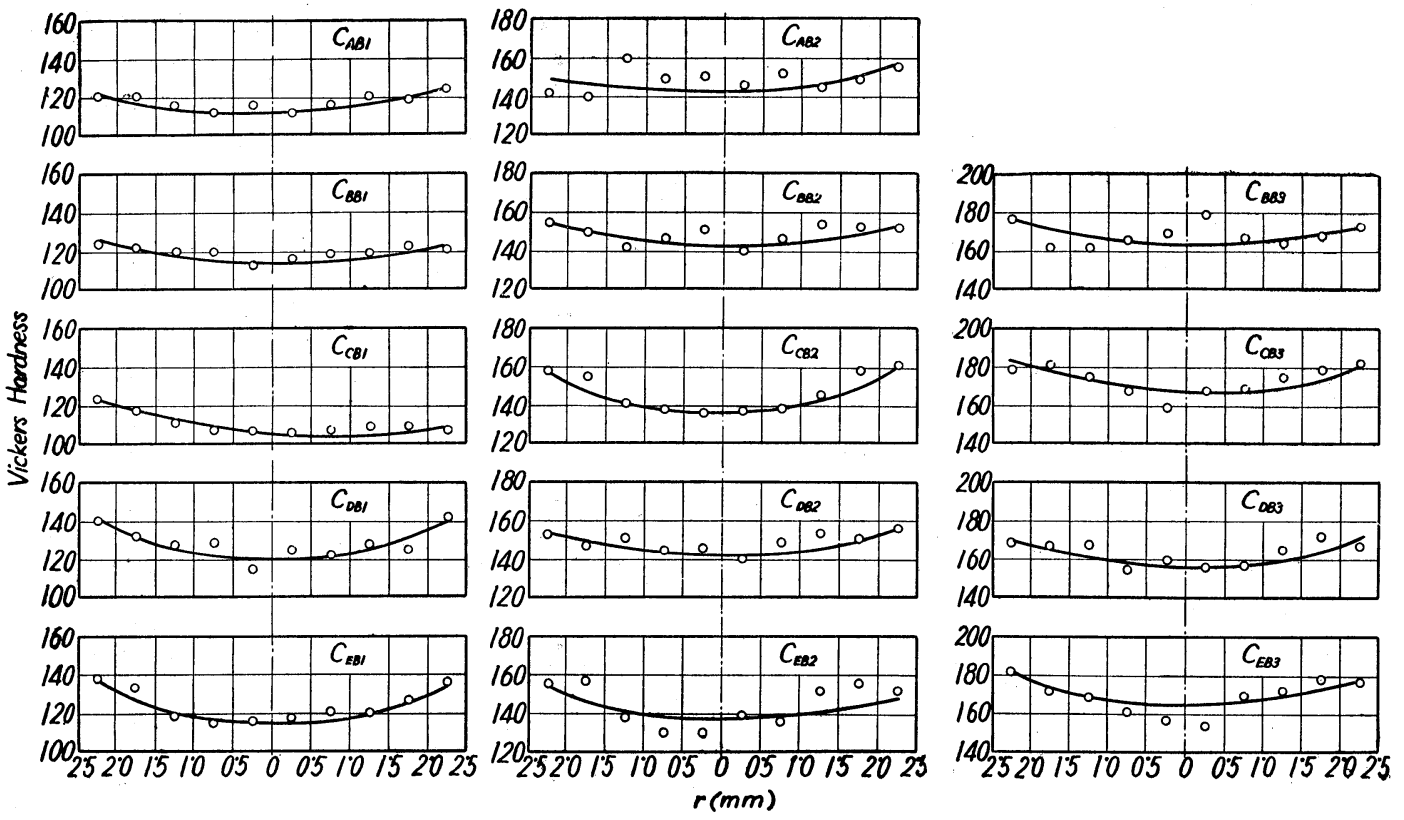

Fig. 6. Hardness distribution of the cross section of the drawn wire (Brass).

Table 4.

\begin{tabular}{|c|c|c|c|c|c|}
\hline \multicolumn{3}{|c|}{ Carbon steel } & \multicolumn{3}{|c|}{ Brass } \\
\hline $\begin{array}{c}\text { Reduction } \\
\text { of diameter } \\
(\%)\end{array}$ & Die & $\begin{array}{c}\text { Sign of } \\
\text { specimen }\end{array}$ & \begin{tabular}{|c}
$\begin{array}{c}\text { Reduction } \\
\text { of diameter } \\
(\%)\end{array}$ \\
\end{tabular} & Die & $\begin{array}{c}\text { Sign of } \\
\text { specimen }\end{array}$ \\
\hline \multirow{5}{*}{$4 \cdot 1$} & $\mathrm{C}_{\mathrm{A}}$ & $\mathrm{C}_{\Lambda} \mathrm{S} 1$ & \multirow{5}{*}{$4 \cdot 1$} & $\mathrm{C}_{\mathrm{A}}$ & $\mathrm{C}_{\mathrm{AB} 1}$ \\
\hline & $\mathrm{C}_{\mathrm{B}}$ & $\mathrm{C}_{\mathrm{BS} 1}$ & & $\mathrm{C}_{\mathrm{B}}$ & $\mathrm{C}_{\mathrm{BB} 1}$ \\
\hline & $\mathrm{C}_{\mathrm{C}}$ & Cosi & & $\mathrm{C}_{\mathrm{C}}$ & $\mathrm{C}_{\mathrm{CB} 1}$ \\
\hline & $C_{D}$ & $\mathrm{C}_{\mathrm{DS} 1}$ & & $\mathrm{C}_{\mathrm{D}}$ & $\mathrm{C}_{\mathrm{DB1}}$ \\
\hline & $\mathrm{C}_{\mathrm{E}}$ & $\mathrm{C}_{\mathrm{ES} 1}$ & & $\mathrm{c}_{\mathrm{E}}$ & $\mathrm{C}_{\mathrm{EB} 1}$ \\
\hline \multirow{5}{*}{$9 \cdot 5$} & $\mathrm{C}_{\mathrm{A}}$ & $\mathrm{CAS}_{\mathrm{A} 2}$ & \multirow{5}{*}{$11 \cdot 6$} & $\mathrm{C}_{\mathrm{A}}$ & $\mathrm{CAB}_{2}$ \\
\hline & $\mathrm{C}_{\mathrm{B}}$ & $\mathrm{C}_{\mathrm{BS2}}$ & & $\mathrm{C}_{\mathrm{B}}$ & $\mathrm{C}_{\mathrm{BB} 2}$ \\
\hline & $\mathrm{C}_{\mathrm{C}}$ & $\mathrm{C}_{\mathrm{CS} 2}$ & & $\mathrm{C}_{\mathrm{C}}$ & $\mathrm{C}_{\mathrm{CB} 2}$ \\
\hline & $\mathrm{C}_{\mathrm{D}}$ & $\mathrm{C}_{\mathrm{DS} 2}$ & & $C_{D}$ & $\mathrm{C}_{\mathrm{DB} 2}$ \\
\hline & $\mathrm{C}_{\mathrm{E}}$ & $\mathrm{C}_{\mathrm{ES} 2}$ & & $\mathrm{C}_{\mathrm{F}}$ & $\mathrm{C}_{\mathrm{EB} 2}$ \\
\hline \multirow{5}{*}{$13 \cdot 6$} & $\mathrm{C}_{\mathrm{A}}$ & $\mathrm{C}_{\mathrm{AS} 3}$ & \multirow{5}{*}{$14 \cdot 4$} & $\mathrm{C}_{\mathrm{A}}$ & $\mathrm{C}_{\mathrm{AB} 3}$ \\
\hline & $\mathrm{C}_{\mathrm{B}}$ & $\mathrm{C}_{\mathrm{BS} 3}$ & & $\mathrm{C}_{\mathrm{B}}$ & $\mathrm{C}_{\mathrm{BB} 3}$ \\
\hline & $\mathrm{C}_{\mathrm{C}}$ & $\mathrm{c}_{\mathrm{CS} 3}$ & & $\mathrm{C}_{\mathrm{C}}$ & $\mathrm{C}_{\mathrm{CB} 3}$ \\
\hline & $\mathrm{C}_{\mathrm{D}}$ & $\mathrm{C}_{\mathrm{DS} 3}$ & & $\mathrm{C}_{\mathrm{D}}$ & $\mathrm{C}_{\mathrm{DB} 3}$ \\
\hline & $\mathrm{C}_{\mathrm{E}}$ & $\mathrm{C}_{\mathrm{ES} 3}$ & & $\mathrm{C}_{\mathrm{E}}$ & $\mathrm{C}_{\mathrm{EB} 3}$ \\
\hline
\end{tabular}

レる.

（3）炭素含有量の影響 炭素含有量が異なるこ とが線材の中心部と外層部との硬度差にどのような影 響を与えるかを調べるために，縦軸に硬度差 $H_{V}{ }^{\prime}$ を， 横軸に炭素含有量をとると，Fig. 17 亿示すように， 硬度差は引抜直径減少率和よびダイスの形状によつて

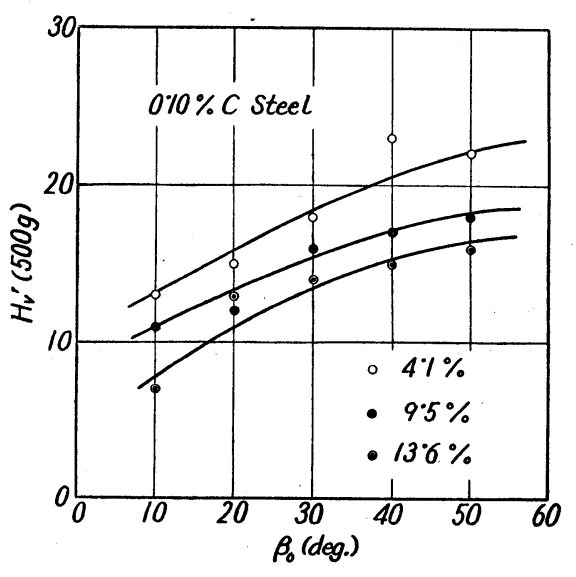

Fig. 7. Effect of the shape of die on the difference of hardness $H_{V}{ }^{\prime}$ between the center and the inner boundary of the cross section of the drawn wire $(0 \cdot 10 \% \mathrm{C})$.
その傾向が異なり，一定の傾向を結論するととはでき ないが, 硬度差 $H_{V}{ }^{\prime}$ と中心部硬度 $H_{V}$ との比を百分率 で表わし，乙れを引抜による断面上の硬度分布の不均 一度とし，乙れを縦軸にとり，横軸に炭素含有量をと ると, Fig. 18 亿示すよ5に, 炭素含有量が増すに従つ て硬度分布の不均一度は減少する傾向を示す。ま， 


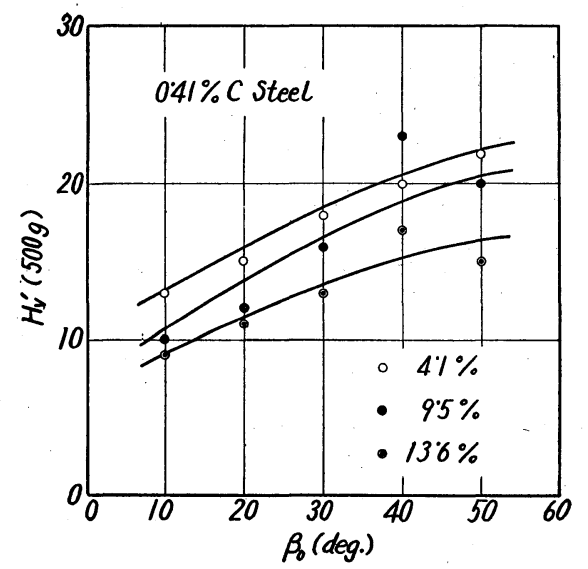

Fig. 8. Effect of the share of die on the difference of hardness $H_{V}{ }^{\prime}$ between the center and the inner boundary of the cross soction of the drawn wire $(0.41 \% \mathrm{C})$.

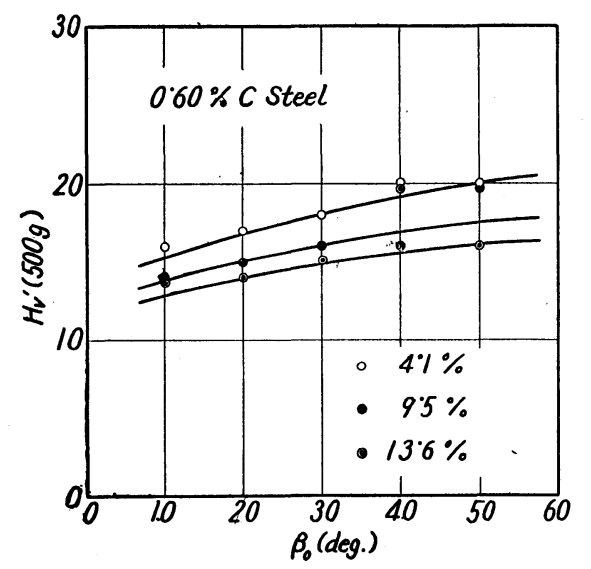

Fig. 9. Effect of the shape of die on the difference of hardness $H_{V}$ ' between the center and the inner boundary of the cross section of the drawn wire $(0.60 \% \mathrm{C})$.

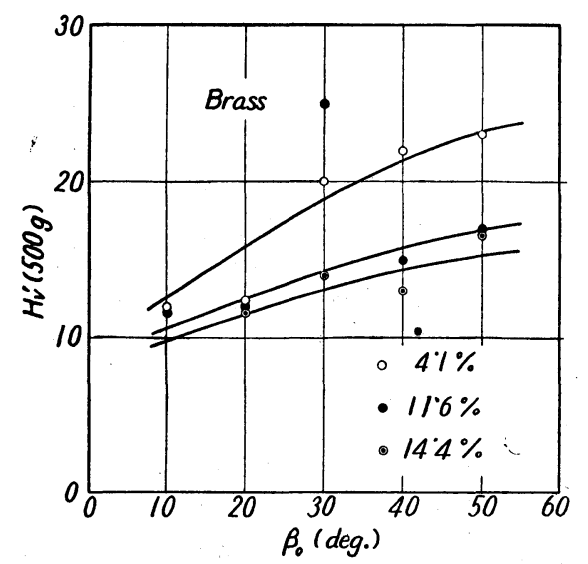

Fig. 10. Effect of the shape of die on the difference of hardness $H_{V}{ }^{\prime}$ between the center and the inner boundary of the cross section of the drawn wire (Brass).

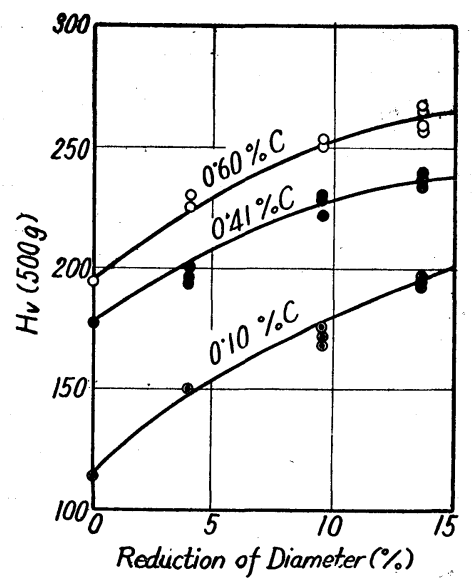

Fig. 11. Relation between the hardness $H_{V}$ at the center of the cross section of the drawn carbon steel wire and the reduction of diameter.

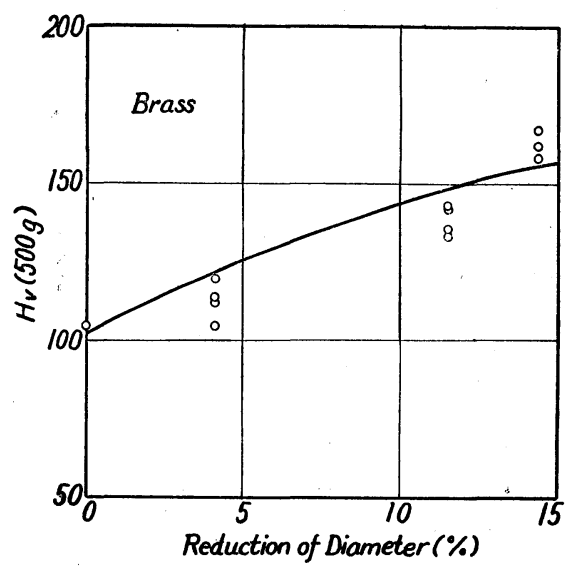

Fig. 12. Relation between the hardness $H_{V}$, at the center of the cross section of the drawn brass wire and the reduction of diameter.

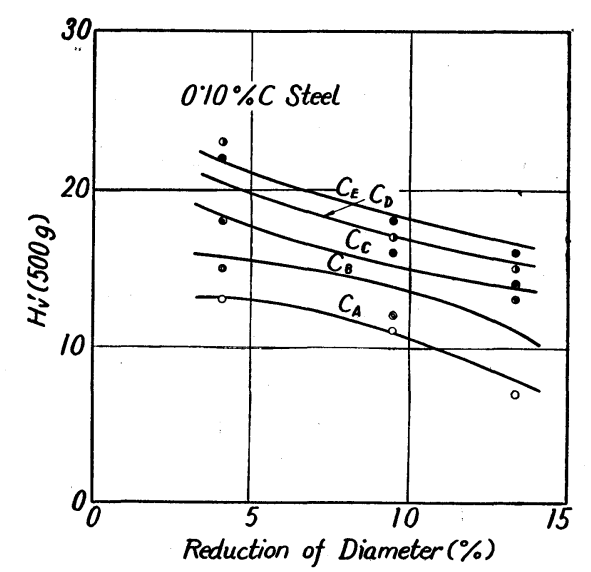

Fig. 13. Effect of the reduction of diameter on the difference of hardness between the center and the inner boundary of the cross section of the drawn steel wire $(0 \cdot 10 \% \mathrm{C})$. 


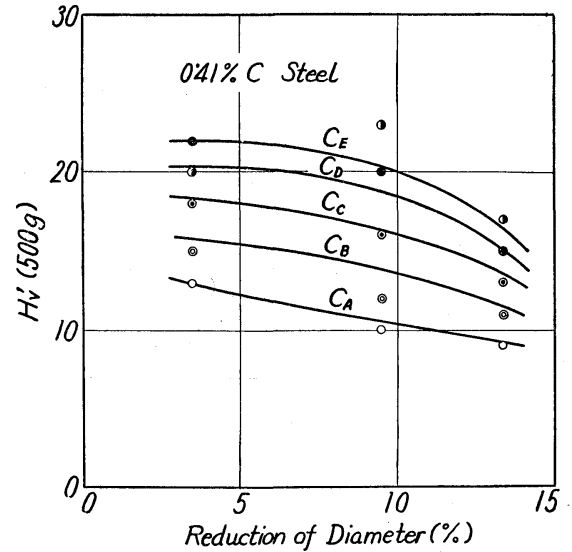

Fig. 14. Effect of the reduction of diameter on the difference of hardness between the center and the inner boundary of the cross section of the drawn steel wire $(0.41 \% \mathrm{C})$.

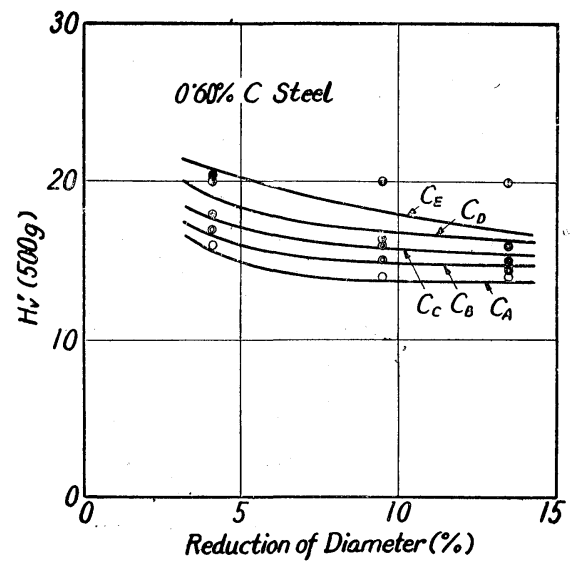

Fig. 15. Effect of the reduction of diameter on the difference of hardness between the center and the inner boundary of the cross section of the drawn steel wire $(0 \cdot 60 \% \mathrm{C})$.
この傾向は加工度の小なるものほど大で, 加工度が大 になるに従つて小になる。

\section{7. 縦断面上の硬度分布}

引抜を途中で中止し，引抜とは逆方向に線材を抜き 取り, 線材の軸学含む面で切断した変形過程に和ける 縦断面上の硬度分布在測定した。.Fig. 19 亿硬度測是 位置の一例を示す. Fig. 20〜Fig. 22 は引拢淔径減少 率 $9.5 \%$ で $\mathrm{C}_{\mathrm{A}}, \mathrm{C}_{\mathrm{C}}$, 和よび $\mathrm{C}_{\mathrm{B}}$ の 3 種類のダイスで 引抜く場合の, 㞸素含有量 $0.10 \%$ の炭素鋼線材の变 形領域に扣ける硬度分布の状態を示すものである。ダ イスの形状が異なることにより硬度の変化の状態もま た異なる。Fig. 23 は中心部と外層部の硬度が変形が 進むとともに増す状態を, 上記 3 種類のダイスについ て比較したものである。ダイス大口の近くで硬度は急 激に増し，出口に近つくに従つて一定值に近づく．外 層部の方は先きに硬度が増し，中心部は外層部に比し

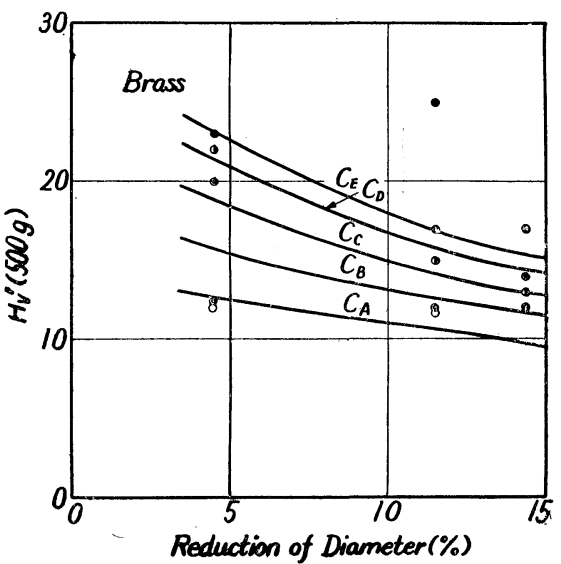

Fig. 16. Effect of the reduction of diameter on the difference of hardness between the center and the inner bounbary of the cross section of the drawn brass wire.
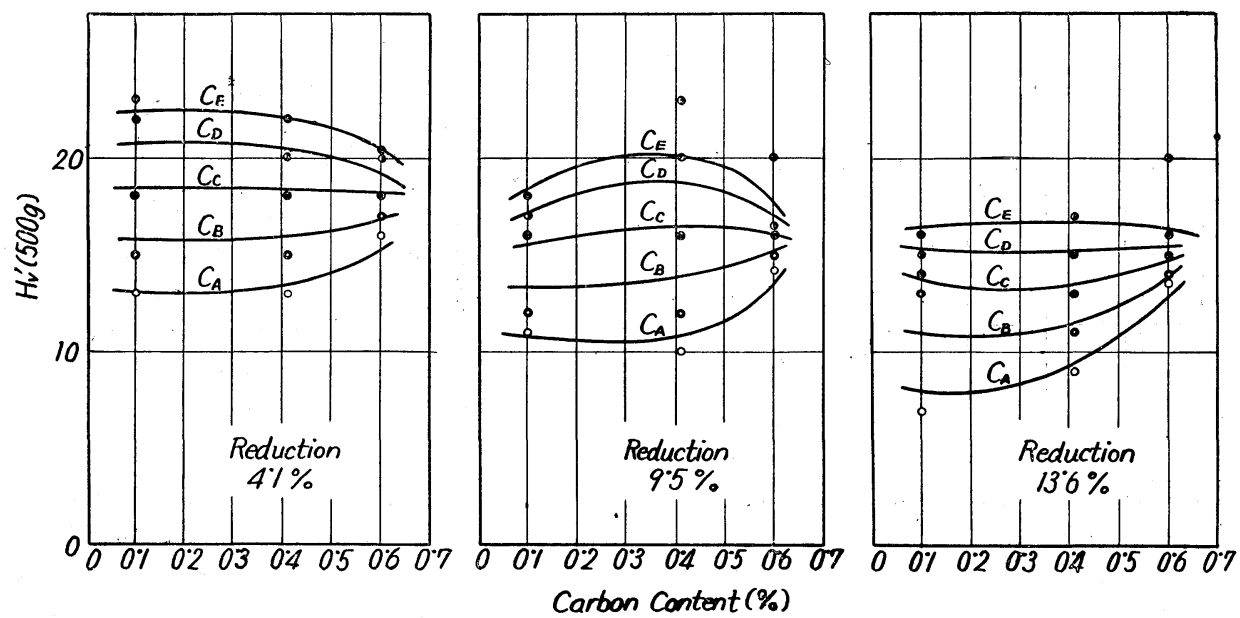

Fig. 17. Effect of carbon content of the drawn wire on the difference of hardness between the center and the inner boundary of the cross section of the drawn wire. 

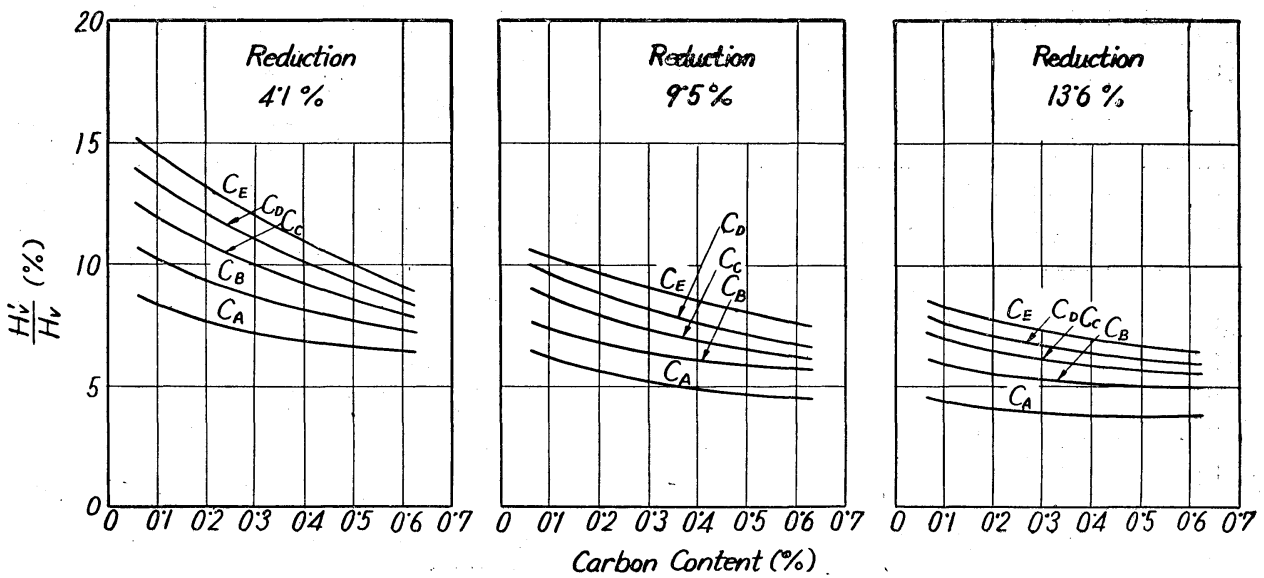

Fig. 18. Relation between the difference of hardness $H_{V^{\prime}}$ and carbon content of the drawn wire.

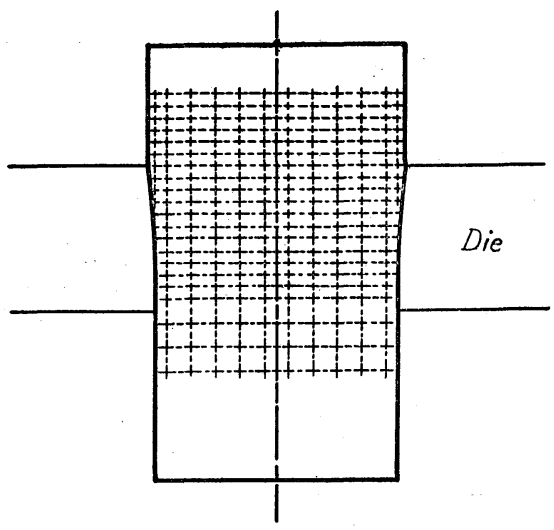

Fig. 19. Half drawn specimen.

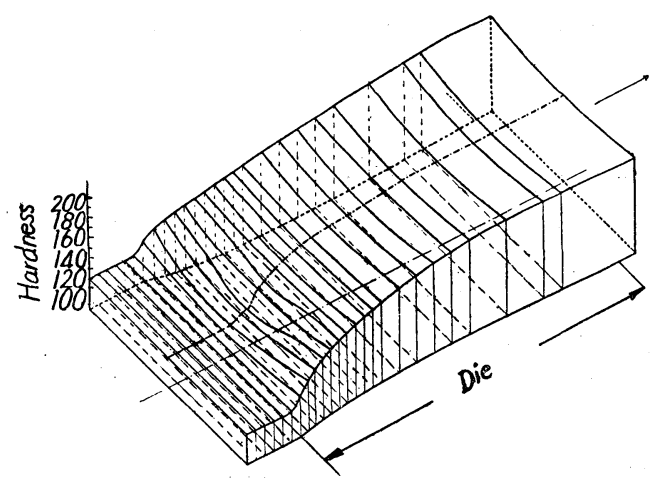

Fig. 20. Gradual change of hardness over the longitudinal section of carbon steel wire under plastic deformation $\left(\beta_{0}=10^{\circ}\right)$.

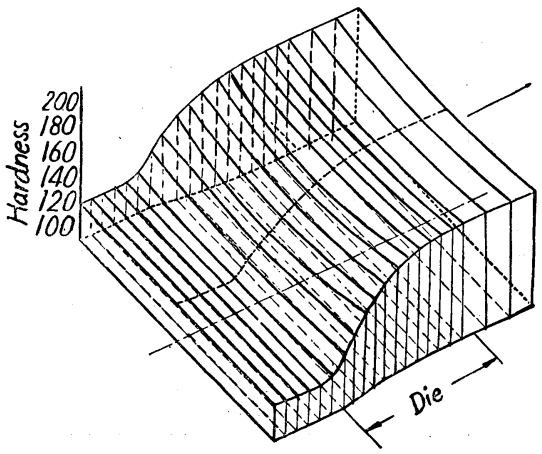

Fig. 21. Gradual change of hardness over the longitudinal section of carbon steel wire $(0.10 \% \mathrm{C})$ under plastic deformation $\left(\beta_{6}=30^{\circ}\right)$.

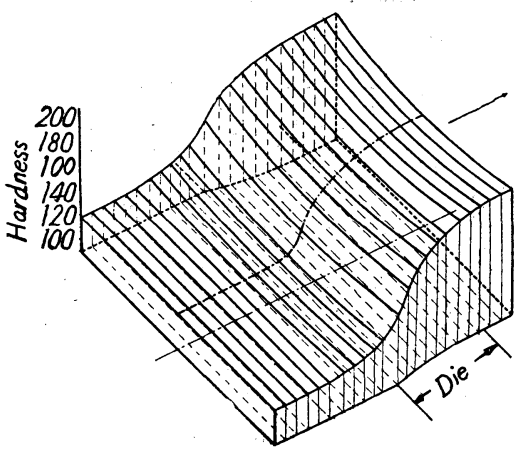

Fig. 22. Gradual change of hardness over the longitudinal section of carbon steel wire $(0.10 \% \mathrm{C})$ under plastic deformation $\left(\beta_{0}=50^{\circ}\right)$. 


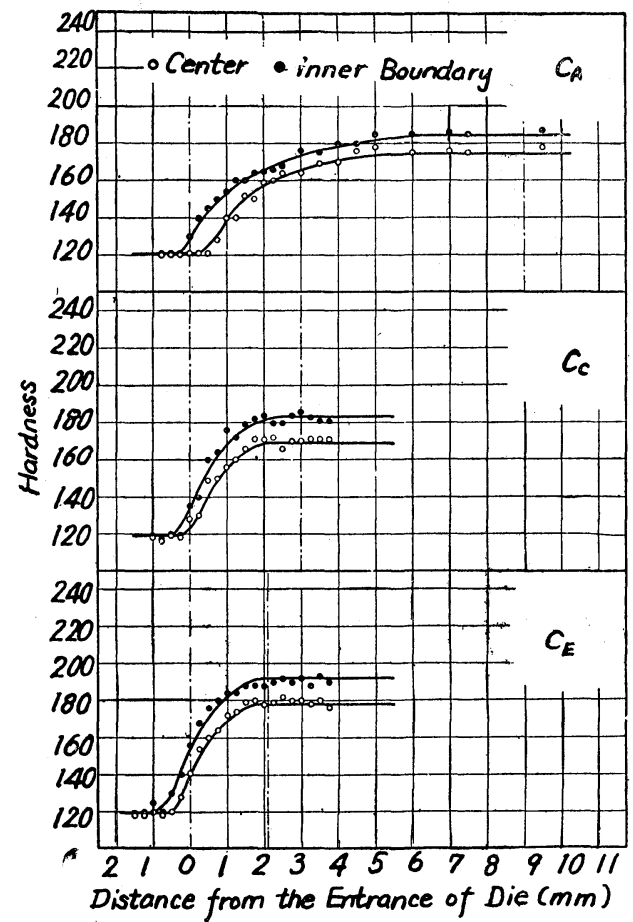

Fig. 23. Change of hardness at the center and the inner boundary of a longitudinal section of a $0.10 \% \mathrm{C}$ steel wire under plastic deformation through a die.

て遅れることが，ま硬度の増加がはじまる位置はが イスの引抜面の形状によつて異なり, 庪面の曲率の
大なる場合ほぞ入口の手前から硬度が増しはじめる。

以上の実験は線材が可抜かれる場合に，変形が進む 飞従つて生吉るととろの硬度分布の変化がダイス形状 によつていかに異なるかを検傠するために行つたもの で，加工度がわずか 1 種類の場合飞過ぎかが，硬度 をもつて変形の程度を知る一つの尺度と考完れば, ダ イス入口の近くでま方線材の外層部が変形を受け，出 口に進むに従つてとの変形が中心部に及び，ダイスの

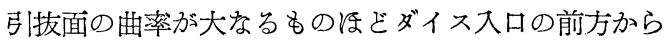
変形を受けはじめるととが推察される。

\section{8. 結 論}

諸種の条件で引抜的を炭素含有量の異なる種類の岸 素鋼線材ならどそ黄銅線材について，横䉼面上の硬度 分布を測定し，引技条件が線材の硬度分布に及ばす影 響を明らかにするととができて，硬度をもつて変形の 程度を表わす一つの尺度と考光れば，断面上飞和ける 硬度差の小な線材活ど均一を变形をうけを線材であ るといらととができる。したがつて引抜面の曲率の小 なるダイスで引拢けば，曲率の大なるダイスを用的る 場合よりも均一な変形をしを線材が得られ，また引抜 直径減少率を大飞すれば，小なる場合よりも均一な変 形をしそ線材を得ることができる，以上のととは 1 回 の引抜についてい光るととで，実際に行わ祅ている多 段引抜の場合については引続いて実験を行う子定であ 万.

注:一

1）鈴木弘, 東宗大学生産技術研究所報告, Vol. 1. No. 3

2) 日本機械学会讅演会講演, 昭和 24 年 10 月

指 示 型 電 気 湿 度 計 ${ }^{*}$ 斎藤幸男** 芹沢竜之介*** 松下顕****

\section{Electrical Instruments Directly Indicating Humidity}

\section{Yukio Saitō, Ryūnosuke Serizawa and Akira Matsushita}

For the purpose of direct indication or recording of humidity, it is reasonable and convenient to use the selenium hygrosensitive elements, formerly developed by the present authers, Saito and Serizawa, inserted in A.C. circuits. In this case, requirements on the characteristics of the elements must be somewhat different from those used in D.C. circuits.

In this paper, manufacturing methods and properties of such purposive hygrometer elements are reported in the first place. Then two different types of electrical instruments directly indicating humidity are introduced. One is A.C. resistancemeter type and the other is automatic balancing A.C. bridge type. They are selectively applicable for the purpose of humidity measurement.

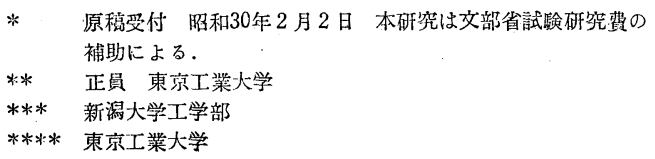

\section{1. 緒 1) 言}

先に報告したセレン感湿要素に対して, 交流回路用 とするための工夫をこらし, あわせて指示型電気湿度 計を得ようとする試みは,先年より続けられていたが, 